\title{
SZOMATOTÍPUS DOMINANCIA ÉS SZEXUÁLIS ÉRÉS
}

\author{
Pápai Júlia ${ }^{1}$, Tróznai Zsófia ${ }^{1}$ és Négele Zalán ${ }^{2}$ \\ ${ }^{1}$ Testnevelési Egyetem, Sporttudományi és Diagnosztikai Laboratórium, Budapest; \\ ${ }^{2}$ Székesfehérvári Teleki Blanka Gimnázium és Általános Iskola, Székesfehérvár
}

Pápai J., Tróznai Zs., Négele Z.: Somatotype dominance and sexual maturation. The purposes of the study were 1) to examine indices of sexual maturation in athlete girls having predominantly endo-, meso- and ectomorph physique; 2) to demonstrate alterations in somatotype by breast maturation. 813 pubertal athlete girls (aged between 10 and 17 years) belonging to different sports events were studied. Somatotype was determined by the Heath-Carter method. Somatotype dominance was decided arbitrarily: the cut-off point was 4.75 unit for the dominant component. The other two components were minimum 1.5 unit below the dominant one. Breast development was rated according to Tanner's suggestions. Data for menarche were collected by "status-quo" method. The age medians of maturation indices were calculated.

Athletes with endomorph dominance matured the earliest. Mesomorphs started to develop their sexual characteristic later than endomorphs and had the latest completion of breast maturation. Girls with ectomorph predominance matured the latest and the fastest. Meso- and ectomorphs preserved their dominant component during breast maturation. Similarly to normal pubescent girls, they increased their relative fatness, but in a different rate. Staying in the mesomorphic endomorph field, endomorphs did not change their body form as maturation proceeded.

Keywords: Somatotype dominance; Breast maturation; Menarche; Female athletes.

\section{Bevezetés}

A sheldoni szomatotípus az emberi alak megközelítésének különleges, egyedi módja. Alapjául a különböző csíralemezekből kifejlődő szervek dominanciájának gondolata szolgál (Sheldon és mtsai 1940). Az egyedi szomatotípust három független komponens endomorfia, mezomorfia, ektomorfia - együttesének tekinti, amelyek segítségével a testalakot egységes egészként ragadja meg. A formabecslő módszer vizuális megtekintésen alapul, a test mérete ebben a rendszerben nem játszik jelentős szerepet. A három domináns faktor egyben a szélsőséges variánsokat reprezentálja.

A dominánsan endomorf szomatotípusra a lekerekítettség jellemző. Szövetei lágyak, csontjai kicsik és vékony kérgűek, a testsürüsége alacsony. A belső szervek közül a táplálkozási rendszer tagjai az uralkodók. A tömeg a test közepére koncentrálódik. A törzs térfogata dominál a végtagoké felett, a has a mellkas felett, és a végtagok proximális szegmensei a disztálisak felett. A legszembetünőbb külső jellemzője a zsírfelhalmozás, amely az abszorptív funkciók túlsúlyának a kifejeződése.

A mezomorf szomatotípus dominanciája a nagy, vastag csontokban és az erőteljes izomzatban nyilvánul meg. Kötőszöveti túlsúly, arányaiban nagy szív- és érrendszer jellemzi. A test szögletes és erős. A törzs nagy és vastag izomzat borítja. A mellkas térfogata jelentősen nagyobb a has térfogatánál. A végtagok izmosak és változatos hosszúságúak. Szembetünőek a vaskos izomzattal borított masszív disztális szegmensek. 
A dominánsan ektomorf szomatotípus esetében a felület arányaiban dominál a tömeg felett. A felületi struktúrák, a bör és származékai, az érzékszervek, valamint az idegrendszer túlsúlyban vannak a belső rendszerek felett. A test lineáris, karcsú és törékeny. A törzs arányaiban rövid, a végtagok hosszúak. A mellkas a hasrégióhoz képest hosszú, a törzs átmérői redukáltak. A végtagok disztális szegmensei proporcionálisan hosszabbak a proximális végtagrészeknél.

Sheldon az egyedi szomatotípust változatlannak tekintette, és úgy gondolta, hogy azt teljes egészében a genotípus határozza meg.

Heath és Carter a sheldoni rendszer fontos elemeit megtartva alakították ki antropometriai szomatotipizálási eljárásukat (Carter és Heath 1990). A módszer végső változata a három komponens relatív dominanciáját csak testméretek alapján állapítja meg. Az első komponens a test relatív zsírosságáról, a második a mozgatórendszer dominanciájáról, a relatív robuszticitásról, míg a harmadik komponens a relatív nyúlánkságról nyújt felvilágosítást.

Az emberek döntő többsége a három komponens különböző mértékü ötvözete, és az egyedi szomatotípusban e komponens arányok fejeződnek ki. Ez az alkati rendszer a fenotípust vizsgálja, így lehetővé teszi a test formájában bekövetkező módosulások nyomon követését.

A szomatotípus skála szélső pontjai az extrém variánsok, akiknek alakjában valamelyik komponens szinte egyeduralkodóvá válik. A testalak szélsőséges kifejeződése kihangsúlyozza a sajátos vonásokat. Sokkal tisztábban mutathatja meg az adott típusra jellemző tulajdonságokat, tulajdonság együtteseket, mint ahol a dominancia nem ilyen erős. Szélsőséges fizikai alkattal gyakran találkozunk a sport világában, sőt vannak sportágak, amelyek megkövetelik az extremitást.

$\mathrm{Az}$ extrém vagy a kifejezetten domináns variánsok tanulmányozására több lehetőség áll rendelkezésre. A komponenseket lehet külön-külön vizsgálni. Mivel Heath és Carter úgy definiálja a szomatotípust, mint az emberi alak és testösszetétel egyfajta becslését (Carter és Heath 1990, Claessens és mtsai 2004), ennek a megközelítésnek van létjogosultsága. Ez esetben azonban pontosan az az információ vész el, ami a becsült alak lényege, a komponensek egymáshoz viszonyított kifejezettsége.

Lehet tanulmányozni a komponensek megoszlását (Bodzsár 1980), amely plasztikusan mutatja a dominanciaviszonyokat. A szomatotípusok differenciálására felhasználhatók a Carter által meghatározott szomatotípus kategóriák (Carter 1975), vagy különböző indexek (Drywien 2016). Az a néhány tanulmány, amelyet e tárgyban találtunk, elsősorban a Carter féle kategóriákra támaszkodott (Bolonchuk 2000, Veldre 2004, Chaouachi és mtsai 2005, Marta és mtsai 2013).

Munkánkban nem extrém alkatú fiatalokat vizsgáltunk. Arra törekedtünk, hogy a három alkati csoportban az adott komponens a másik kettőhöz viszonyítva kifejezett legyen, jelezze a komponens dominanciát. Az így elkülönített serdülőknél a testalkat és a szexuális érés közötti kapcsolatot elemeztük.

Célkitüzéseink a következők voltak: 1) a szomatotípus dominancia alapján csoportosított sportolónők szexuális érésének vizsgálata, illetve 2) a szomatotípusban bekövetkező változások tanulmányozása az emlő fejlődésének stádiumai szerint. 


\section{Vizsgált személyek és alkalmazott módszerek}

A tanulmány alanyait a munkacsoportunkban 1990 és 2010 között vizsgáltak adatbázisából válogattuk. A lányok mindannyian egyesületi sportolók voltak. Az anyag heterogén volt többek között a sportképességek, az eredményesség, a sportmúlt és az edzésterjedelem tekintetében. A vizsgálatba került sportolók 21 sportágat képviseltek, közülük 35\% az állóképességi, 31\% a torna, 29\% a labdajátékok, 5\%, a küzdö sportági csoportokba tartozott.

Az adatbázisból azok kerültek kiválogatásra, akikre valamelyik szomatotípus komponens dominanciája volt a jellemző. A komponensdominanciát eredetileg magasabb értékre terveztük. Limitáló faktornak a II. komponens bizonyult; még a sportoló lányoknál sem volt egyszerü feladat kifejezetten mezomorf túlsúlyú fiatalokat találni. A dominancia alsó határát végül 4,75 egységben határoztuk meg. A másik két komponens számértéke a domináns faktor aktuális értékénél legalább 1,5 egységgel volt kevesebb. Az így kiválasztott sportolók megoszlása az 1. táblázatban látható. A legnépesebbnek a dominánsan ektomorf lányok csoportja bizonyult. A táblázatból az is kiolvasható, hogy a mezomorf dominancia inkább a szexuális érés korai stádiumaiban, míg az endomorf dominancia a késői fokozatokban volt jellemzőbb. Ez a leányok testfejlődési jellemzőinek ismeretében könnyen magyarázható.

1. táblázat. A vizsgált sportolónők megoszlása az emlő érési fokozatai és a szomatotípus komponensek dominanciája szerint.

Table 1. The distribution of female athletes by maturation stages of breast and by the dominance of somatotype components.

\begin{tabular}{lcccc}
\hline & \multicolumn{3}{c}{$\begin{array}{c}\text { Szomatotípus komponens dominancia - } \\
\text { Somatotype component dominance }\end{array}$} \\
$\begin{array}{l}\text { Emlö érési fokozatai - Maturation } \\
\text { stages of breast }\end{array}$ & $\begin{array}{l}\text { Endomorf - } \\
\text { Endomorph }\end{array}$ & $\begin{array}{c}\text { Mezomorf - } \\
\text { Mesomorph }\end{array}$ & $\begin{array}{c}\text { Ektomorf }- \\
\text { Ectomorph }\end{array}$ & $\begin{array}{c}\text { Együtt - } \\
\text { Together }\end{array}$ \\
\hline B1 & 29 & 60 & 72 & 161 \\
B2 & 28 & 50 & 55 & 133 \\
B3 & 38 & 50 & 79 & 167 \\
B4 & 57 & 43 & 91 & 191 \\
B5 & 71 & 32 & 58 & 161 \\
Együtt - Together & 223 & 235 & 355 & 813 \\
\hline
\end{tabular}

A gyermekeket attól az életkortól kezdve vontuk be a feldolgozásba, amely kortól az emlő kifejlődésének első jelét (B2) tapasztaltuk. Felső határnak azt az életkort tekintettük, amelyben még megfigyelhető volt fejlödésben lévő fiatal (B4). A vizsgálatban átfogott életkori intervallum 10 és 17 év között volt.

A hosszúsági, szélességi, kerületi és bőrredő méreteket a standard leírás alapján (Martin és Saller 1957/1966, Bodzsár és Zsákai 2004), a Nemzetközi Biológiai Program ajánlásait (Tanner és mtsai 1969) figyelembe véve vettük fel. A szomatotípus komponenseket Heath és Carter módszerével (Carter 1975), Szmodis (1977) regresszióegyenletei alapján számítottuk. A szomatopontok átlagos szóródását az SDM (mean somatotype dispersion) mutatóval jellemeztük (Ross és mtsai 1977).

A szexuális érés indikátorai közül az emlő fejlődésének stádiumait (B1-B5) megtekintéssel vizsgáltuk (Tanner 1962). A menarche bekövetkeztére vonatkozó adatokat 
status quo módszerrel gyüjtöttük. Az emlő fokozatainak megjelenési idejére kormediánt számítottunk, a csoportok menarche medián értékét probit analízis segítségével állapítottuk meg (Weber 1969).

\section{Vizsgálati eredmények és értékelésük}

Az 1. ábrán a szomatotípus dominancia alapján kialakított csoportok szomatopontjainak átlagát tüntettük fel és kiszámítottuk a szomatotípus diszperziós indexet (SDM), amely a szomatopontok átlagos megoszlását mutatja.

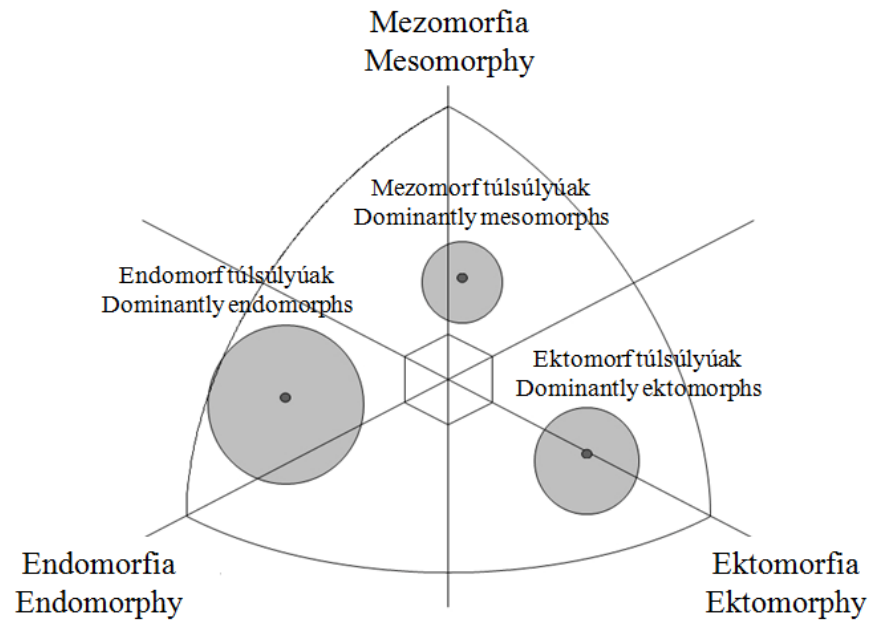

1. ábra: A szomatotípus komponensek dominanciája alapján elkülönített csoportok (॰: csoportok szomatopont átlaga, ๑: a leányok szomatopontjainak alkati csoportra jellemző SDM érték alapján becsült szóródása a csoportok átlagos szomatopontja körül).

Fig. 1: The groups separated on the basis of somatotype component dominance (॰: mean somatoplots, : the dispersion of girls' somatotypes based on the SDM values around the mean somatotypes).

A dominánsan mezo- és ektomorf alkatúak szomatopont átlaga az egyensúlyos mezőbe esett, míg az endomorf dominanciával rendelkezőké a mezomorfiás endomorf mezőbe került. Az átlagos szomatopont körüli körök jól mutatják, hogy testalak szempontjából a mezomorf túlsúlyú lányok voltak a leghomogénebbek, az endomorfok pedig a legszórtabbak.

Az érés mutatói szerint (2. táblázat) az emlő kifejlődése legkorábban a dominánsan endomorf, míg legkésőbben a dominánsan ektomorf alkatú leányoknál indult meg. Amennyire a fokozatmediánok időkülönbségeiből becsülhető, a leggyorsabban az ektomorf dominanciával bírók haladtak keresztül az emlőfejlődés stádiumain, míg a leglassabb fejlődést a mezomorf alkatúaknál találtuk. A hazai standardhoz képest (Bodzsár és Zsákai 2012, Bodzsár és mtsai 2013) még a legkorábban fejlődő endomorf alkati túlsúllyal jellemzett csoportnál is későbbi életkorban indult a szexuális érés.

A hazai sportoló gyermekek másodlagos nemi jellegeinek fejlődéséről az 1980-as évektől vannak adataink (Pápai 1996, 2002, Pápai és mtsai 2012, László 1998). A különböző mintákon végzett elemzések szerint a lányoknál az emlő fejlődése 11 éves kor 
körül indul és a felnőttnek jelölt B5 állapotba átlagosan 3,5 év alatt ér el. Az egymást követő fázisok megjelenése között 0,8-1,2 év a különbség. A jelen anyagban ez a mintázat csak az ektomorf túlsúlyúak esetében és csak a fejlődési fokozatokra teljesül. A dominánsan endo- és mezomorf alkatúaknál a B4 és B5 stádiumokba való eljutás ennél jelentősen hosszabb időt vesz igénybe.

2. táblázat. Az érés indikátorainak kormediánjai ( \pm szórás; év) és a menarchekor 95\%-os konfidencia intervalluma a szomatotípus komponensek dominanciája szerint.

Table 2. The median age ( \pm SD; years) of sexual maturation indices and the $95 \%$ confidence interval of menarcheal age by the dominance of somatotype components.

\begin{tabular}{llll}
\hline $\begin{array}{l}\text { Érési indikátorok - } \\
\text { Sexual maturation indices }\end{array}$ & $\begin{array}{l}\text { Endomorf }- \\
\text { Endomorph }\end{array}$ & $\begin{array}{l}\text { Mezomorf }- \\
\text { Mesomorph }\end{array}$ & $\begin{array}{c}\text { Ektomorf - } \\
\text { Ectomorph }\end{array}$ \\
\hline B2 & $10,40 \pm 0,23$ & $11,40 \pm 0,37$ & $11,63 \pm 0,44$ \\
B3 & $11,22 \pm 0,31$ & $12,22 \pm 0,42$ & $12,53 \pm 0,23$ \\
B4 & $13,04 \pm 0,28$ & $13,79 \pm 0,54$ & $13,34 \pm 0,24$ \\
B5 & $14,54 \pm 0,24$ & $15,30 \pm 0,51$ & $14,91 \pm 0,43$ \\
Menarche & $12,42 \pm 0,16$ & $13,68 \pm 0,23$ & $14,05 \pm 0,14$ \\
$95 \%$ CI & $12,11-12,74$ & $13,22-14,14$ & $13,79-14,32$ \\
\hline
\end{tabular}

95\% CI: menarchekor 95\%-os konfidencia intervalluma - 95\% confidence interval of menarcheal age

A lányok érésének másik igen fontos indikátora a menarche, az első menstruáció bekövetkezési ideje. Számos adat igazolja, hogy a normál populációhoz képest a sportoló nők később kezdenek menstruálni (Erdélyi 1962, Malina és mtsai 1978, Malina 1986, Malina és Bouchard 1991, Claessens és mtsai 1992, Farmosi 1992, Baxter Jones és mtsai 1994). A jelenség hátterében összetett, eddig még nem teljesen felderített hatásrendszer áll, amelynek egyik fontos eleme a sportági szelekció (Malina 1983, Pápai és mtsai 2012). A hazai sportolói mintákban a menarche medián 13,1 és 13,5 év között variált, ami a magyar lányok menarchekorához képest (Bodzsár és mtsai 2013) mintegy 0,3-0,7 év késést jelent. Ez azt jelzi, hogy még a kevésbé szigorú kiválasztásnak alávetett serdülőkorúak esetében is megfigyelhető a késői fiziológiás érés.

A 2. táblázatban feltüntettük a vizsgált csoportok menarche medián értékét is. Legkorábban az endomorf, legkésőbben az ektomorf túlsúlyú lányok kezdtek menstruálni. A hazai standard mediánhoz képest a dominánsan endomorf alkatú sportolónőknél a menarche korábban, míg a mezo- és ektomorf dominanciával bíró csoportoknál későbben következett be.

A későbbi menarche a nemi jellegek későbbi kifejlődésével kapcsolódik össze és fordítva. Sportoló lányoknál (László 1998, Balázs és László 2006) longitudinális mintában szoros pozitív kapcsolatot találtunk az első menstruáció megjelenése és az emlő fejlődési fázisaiba (B2-B4) való belépés ideje között ( $r=0,81-0,87)$, ami a két érési bélyeg időzítésének szoros kapcsolatára utal. Nem sportoló leányoknál (Bodzsár és Pápai 1989) a kapcsolat szintén igen szorosnak bizonyult ( $\mathrm{r}=0,92)$. Az irodalmi adatok szerint a menarche a lányok nagy többségénél az emlő fejlődésének negyedik stádiumában jelenik meg (Tanner 1962, Tanner és mtsai 1976, Malina 1986, Malina és Bouchard 1991, Bodzsár 2001, 2003). Ugyanezt figyeltük meg a sportolói mintákban is (Pápai 1996, 2002, Pápai és mtsai 2012). Azonban a szomatotípus dominancia alapján kialakított csoportjaink közül - amennyire a fokozatmediánok és a menarche medián összevetése 
alapján kikövetkeztethető - ez a mintázat csak a dominánsan mezomorf sportolókra volt jellemző. A legkorábban érö, endomorf dominanciával jellemzett lányok esetében a menarche a B3 és B4 stádiumok között, míg az ektomorf túlsúlyú leányoknál a B4 és B5 stádiumok között következett be.

A szomatotípus dominancia és az érés kapcsolatával foglalkozó tanulmányok nem alkotnak túl nagy halmazt. Sheldon és munkatársai (1940) az emberi alkatról szóló könyvükben az endokrin funkciók és az alkat kapcsolatáról írt fejezetben megemlítik, hogy a harmadik komponens dominanciája hajlamos késleltetni a szexuális érést, míg az első két komponens mérsékelt túlsúlya sietteti azt. Tanner már 1955-ben megjegyezte, hogy az endomorf alkatú lányoknál a menarche korábban jelenik meg, mint az ektomorf túlsúlyúaknál (cit. Susanne és Bodzsár 2004). Hunt és munkatársai (1958) arról számoltak be, hogy a fiúknál az ektomorfia mint domináns jelleg, a késői érési folyamatokhoz kapcsolódik. A mezomorf túlsúlyú gyermekek nemi jellegei korán indulnak fejlődésnek, míg az endomorf dominanciájú fiatalok nemi érése szintén korán indul, de érési folyamataik elhúzódóak, érésük sebessége a három csoport közül a leglassúbb. A jelen dolgozatban nagyon hasonló eredményeket kaptunk azzal a különbséggel, hogy a lányoknál a dominánsan mezomorf alkatúak érése volt a leglassúbb.

Bodzsár $(1980,1991)$ adatai szerint a túlnyomórészt endomorf testalkatú lányok korábban érnek, mint az ektomorf túlsúllyal bírók. Hasonló eredményre jutottak Rahmawati és munkatársai (2017), akik azt találták, hogy az ektomorfia emelkedésével nő, az endomorfia emelkedésével csökken a menarchekor. Ugyancsak alátámasztotta eredményeinket Veldre kutatása (2004), aki a föbb szomatotípus kategóriákba tartozó gyermekek érési paramétereit vizsgálta. Adatai szerint a kiegyensúlyozott endomorf és az endomorfiás mezomorf mezőbe tartozók menstruálnak a legkorábban. A későn érők az ektomorfia tengelye körül sürüsödnek, de az egyes kategóriák reprezentánsainak mediánjai között csak árnyalatnyiak a különbségek.

Izgalmas kérdés, hogy vajon a fordított megközelítés - azaz amikor a szexuális érés, az érési típus alapján elkülönített csoportok szomatotípusának különbségeit tesszük vizsgálat tárgyává - hasonló eredményekre vezet-e. Az egyik legkorábban megjelent tanulmány szerzője (Zuk 1958) a lányoknál a korán érőket endomorfabbnak és kevésbé ektomorfnak találta, mint a későn érőket. A későbbi vizsgálati adatok is mind hasonló eredményre vezettek: a korán érők robusztusabb és relatíve zsírosabb, míg a későn érők lineárisabb testfelépítésủnek bizonyultak (Bodzsár 1980, 1991, 2003, Pápai 1985, Pápai és Szabó 1986, Pápai és mtsai 2013).

A továbbiakban megvizsgáltuk, hogy az alkati dominancia alapján csoportosított leányoknál az emlő fejlődése során történik-e változás a szomatotípusban. Az endomorf túlsúlyú leányok átlagos szomatotípusát megjelenítő szomatopontok a mezomorfiás endomorf mezőben helyezkedtek el (2. ábra). Az emlő kifejlődési fokozataihoz nem volt köthető semmilyen irányultság, határozott vándorlási tendencia. A mezomorf túlsúlyú sportolónők szomatopontja az érés megindulása előtt (B1) az ektomorfiás mezomorf mezöben volt. Először kissé csökkent a mezomorfia kifejezettsége, majd az érés végéig változatlan maradt, miközben az endomorfia komponensének növelésével és az ektomorfia csökkentésével az endomorfiás mezomorf mezőbe értek el. Az ektomorf túlsúlyú csoport a mezomorfiás ektomorf mezőből az endomorfiás ektomorf mezőbe jutott el. A vándorlás során a stabilan tartott ektomorfia mellett kissé növelték az endomorfia, és számottevően csökkentették a mezomorfia komponensét. A szexuális érés folyamán tehát a dominánsan endomorf csoport kivételével a szomatopontok határozott 
irányba történő vándorlása volt megfigyelhető. E két utóbbi csoport a domináns faktor állandó szinten tartása mellett a női nemre jellemzően növelte az endomorfia komponensét.

Egy korábbi tanulmányunkban az emlő fejlődési fokozatai szerint vizsgáltuk a sportoló lányok szomatotípus változásának irányvonalát (Pápai 2001). A serdülés megindulásakor a szomatopontok átlaga a mezomorfiás ektomorf mezőben volt, a vándorlás során a centrális mezöt érintve az egyensúlyos endomorf mezőbe jutott el. A fejlődési stádiumokon (B2-B4) való áthaladás során jelentősen csökkent a mezomorfia komponense, majd a B4 stádium után megtartott mezomorfia szint mellett az endomorfia komponense vált dominánssá. A normál lányoknál (Bodzsár 2003) lényegében hasonló irányú vándorlást lehetett megfigyelni, csak a mezomorfia sokkal kevésbé volt kifejezett, mint a sportolóknál. A szomatotípus komponensek dominanciája alapján képzett csoportjainkban ez az általánosnak mondható irányvonal egyáltalán nem volt fellelhető.

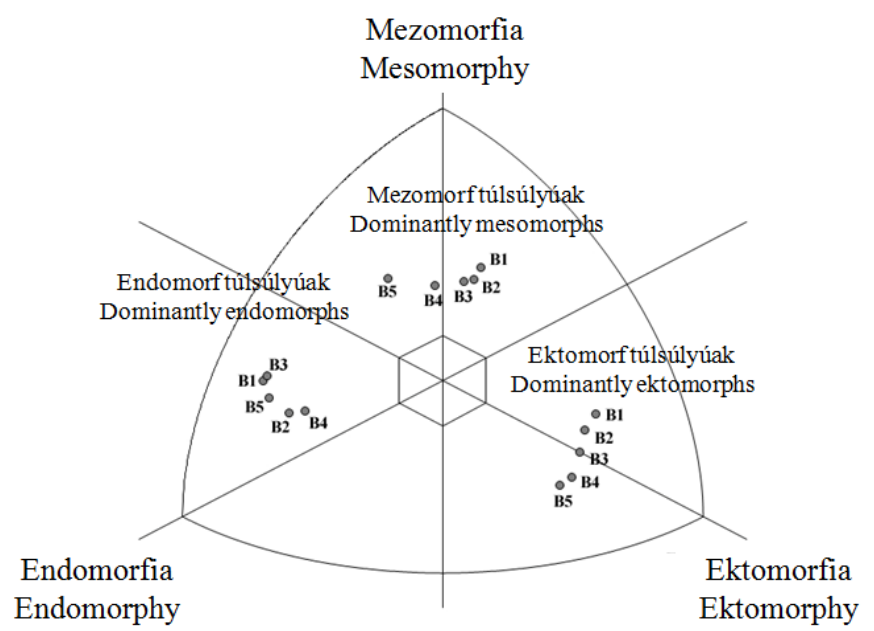

2. ábra: Az átlagos szomatopontok elhelyezkedése az emlő fejlődésének stádiumai szerint (B1-B5) a szomatotípus komponensek dominanciája alapján elkülönített csoportokban.

Fig. 2: The position of mean somatoplots by the stages of breast maturation (B1-B5) in the groups separated on the basis of somatotype component dominance.

Korán és későn érő sportolók szomatopontjainak vándorlását vizsgálták Pápai és munkatársai (2013) szintén az emlő fejlődése szerint. A két csoport szomatopontjai a testtérkép eltérő területein helyezkedtek el, egyébként követték az elöbbiekben a sportolókra bemutatott vándorlási mintázatot. A későn érők lineárisabb testfelépítésüek voltak, különösen a szexuális érés korai stádiumaiban. Pápai és Szabó (1986) nem sportoló lányokat a menarchekoruk alapján csoportosítva azt találták, hogy a nagyon korán érő lányok extrém mezo-endomorfok voltak és a vizsgált időintervallumban endomorfiájukat tovább fokozták.

Az érés különbözö indikátorai alapján kapott vizsgálati adatok tehát azt mutatják, hogy a kortársaiknál korábban érő lányok testalkatában - legyenek akár sportolók vagy nem sportolók - az endomorfia komponense dominál, míg a későbben fejlődőkre a kifejezettebb ektomorfia a jellemzö. Tanulmányunk eredményei ugyanezt egy másik nézőpontból erősítették meg. 
Arra vonatkozóan, hogy a már induláskor is szélsőséges szomatotípus hogyan változik a szexuális fejlődés során, nehéz pontos választ adni. Ehhez célzott longitudinális vizsgálatokra lenne szükség. Feltételezzük - amint azt az általunk bemutatott elrendezésben is tapasztaltuk, hogy a komponensdominancia stabil marad. Különösen igaz lehet ez az ektomorfia komponensére, de a csont- és izomkerületekre alapozott relatív muszkularitás genetikai faktora sem elhanyagolható (Malina és Rarick 1973, Peeters és mtsai 2007). Ezt a gondolatot támasztja alá az is, hogy a lányoknál az öröklődés jobban befolyásolta a mezo- és ektomorfia faktorát, míg az endomorfia komponense környezeti hatásoknak való kitettsége nagyobb (Skibinska és Sklad 2004).

A tanulmányunkban bemutatott adatok, valamint a hivatkozott irodalmak a testalkat és a szexuális érés közötti kapcsolatot tárták fel, és azt mutatták, hogy a szomatotípus komponensek dominanciája és az érési típus egymással kapcsolatban van. Ez csak egy szempont és csak egy kis szelete az érésre vonatkozó szerteágazó humánbiológiai vizsgálatoknak. Ebbe a hatalmas folyamba csatlakoztathatók a testösszetétel és az érés kapcsolatát taglaló munkák, a szekuláris trend azon vonatkozásai, amelyek az érés korábbra tolódásának jelenségét kutatják, valamint ugyanebbe a családba tartoznak azok a kutatások is, amelyek az elhízás és az érés kapcsolatával foglalkoznak. Az e tárgykörökbe tartozó számtalan tanulmány egyértelmüen jelzi, hogy a test zsírtartalma és a szexuális érés időzítése kapcsolatban van egymással, nevezetesen, hogy a korábbi éréshez emelkedett testzsírtartalom kapcsolódik és fordítva. Az a kérdés, hogy milyen mechanizmus(ok) állnak a pubertás megindulása hátterében, milyen szignál(ok) és hogyan indítják el a nemi érést, régóta az érdeklődés homlokterében áll. A múlt században e kérdésben több feltételezés is született. Kennedy és Mitra (1963) úgy gondolták, hogy a serdülés időzítése a test energia szabályozásán alapul. Állatkísérletek alapján arra következtettek, hogy a táplálékbevitel és annak az anyagcserével való összefüggése fontos jel lehet a pubertás megindulásában.

Jól ismert a kritikus testtömeg hipotézis, amely ok-okozati kapcsolatot feltételez a testtömeg adott mennyisége és a menarche megjelenése között. Később a hipotézist finomították, mert kiderült, hogy a testösszetétel, nevezetesen a zsírtömeg jobb elörejelzője volt a pubertás indításának, mint önmagában a testtömeg. Még később nagyobb hangsúly került az anyagcserefolyamatok szerepére (Frisch 1972, 1980, Frisch és McArthur 1974).

Felvetődik a kérdés, hogy vajon a testzsír mennyisége/aránya befolyásolja-e a pubertás indulását, avagy a korai/késői érés szabályozza a zsírtartalmat. Vannak, akik a szexuális érés hatásának tulajdonítanak nagyobb jelentőséget (Garn és mtsai 1986, Wang 2002, Demerath és mtsai 2004), de a bizonyítékok többsége arra utal, hogy a lányok serdülésének időzítésében a megemelkedett zsírtartalom a kritikus faktor (Kaplowitz és mtsai 2001, Davison és mtsai 2003, Ebling 2005).

A zsírszövetről alkotott tudás gyarapodásával derült fény arra, hogy a zsírsejtekben szintetizálódó hormonoknak és hormonszerủ anyagoknak nagy jelentőségük van többek között az energiaegyensúly fenntartásában, a metabolikus folyamatokban, a reprodukcióban, a szív- érrendszeri müködésekben, valamint az immunfolyamatokban (Trayhurn és Beattie 2001, Meier és Gressner 2004, Wells 2012, Wronska és Kmiec 2012). A kutatók a zsírsejtek által termelt leptin nevü hormonnak tulajdonítanak szerepet a pubertás indításában (Considine és mtsai 1996, Foster és Nagatani 1999, Meier és Gressner 2004, Dar és mtsai 2017), de maga a pontos mechanizmus nincs még megnyugtatóan feltárva. A leptin közremüködik az energiaegyensúly szabályozásában, 
együttmüködik a reproduktív tengellyel, számos ponton serkentő hatást gyakorolva a hipofízisre és a hipotalamuszra (Meier és Gressner 2004, Dar és mtsai 2017). A leptin szekréciója a periférián kapcsolatban van a testtömeggel és a testzsírtömeggel, valamint annak regionális megoszlásával (Lassek és Gauli 2007); jelzi a központi idegrendszernek a periféria energia ellátottságát. Matkovic és társai (1997) longitudinális mintában a szérum leptin hatását vizsgálták a menarche időzítésére. A szerzők szerint a vérben lévő leptinnek el kell érni egy kritikus szintet a fiatal nök reproduktív képességeinek kiváltásához. Véleményük szerint a késői pubertás elsődleges oka a leptin deficit.

Úgy tünik, hogy a leptin lehet az az összekötő kapocs a zsírszövet, az energia homeosztázist szabályozó hipotalamikus központok és a reproduktív rendszer között, amely jelzi, hogy a normál reproduktív müködéshez vajon rendelkezésre állnak-e a megfelelö energiatartalékok (Meier és Gressner 2004). Kaplowitz (2008) szerint a zsírszövet és a reproduktív tengely közötti kapcsolat olyan mechanizmusként fejlödhetett ki, amely arról gondoskodik, hogy a fogamzás és az utód kihordása ne következhessen be addig, amíg az anya és a fejlődő magzat biztonságát lehetővé tevő zsírraktárak nincsenek feltöltve.

\section{Összefoglalás}

- A szomatotípus dominancia alapján csoportosított sportoló lányoknál a normál populációhoz képest az érési paraméterek késői időzítése figyelhető meg.

- A különböző alkati dominanciával bíró csoportok érési mintázatában a különbségek föként a pubertás második felében válnak nyilvánvalóvá.

- Az emlő fejlettségi stádiumainak időviszonyai a középfázisig a „reguláris” menetet követik. A B3 stádium utána e nemi jelleg kifejlödése a sportoló leányoknál nagymértékben lassul. Ez alól csak az ektomorf túlsúlyú csoport tekinthetö kivételnek.

- A menarche csak a köztes időben érő mezomorf túlsúlyú lányoknál következik be a B4 stádium medián értéke körül. A korán érő, endomorf túlsúlyú alkatúak többsége ennél korábban, a későn érő dominánsan ektomorf alkatúak többsége pedig ennél későbben kezd menstruálni.

- Az érés folyamata leggyorsabb az ektomorf alkati túlsúlyú sportolóknál. A mezomorf és endomorf alkatú leányok nemi jellegei lassabban, közel azonos idő alatt fejlödnek ki. Ez a különbség az anyagcsere folyamatok gyorsaságával hozható összefüggésbe.

- Azok a leányok, akikre valamelyik alkati komponens túlsúlya jellemzö, különbözö kronológiai életkorban és eltérő sebességgel érnek.

- A szexuális érés idején az ekto- és mezomorf túlsúlyú csoport megőrzi a rá jellemző komponens dominanciát, miközben növeli testének zsírtartalmát. A dominánsan endomorf csoportban nem történik változás, az amúgy eléggé magas testzsírtartalom mintegy kompenzációként- stabil marad.

- A szomatotípus dominanciával jellemzett csoportok mindegyike a maga sajátos módján tölti fel azokat az energiaraktárakat, amelyek a reprodukciós folyamatok megindulásához szükségesek.

A tanulmányt dr. Bodzsár Évának ajánljuk 70. születésnapja alkalmából. 


\section{Irodalom}

Balázs, N., László, A. (2006): Sportoló fiúk érése és testösszetétele. In: Pápai, J. (Szerk.) Fejlődés, fizikai aktivitás, egészség. Alfadat Press, Tatabánya-Budapest. 39-47.

Baxter-Jones, A.D., Helms, P., Baines-Preece J., Preece, M. (1994): Menarche in intensively trained gymnasts, swimmers and tennis players. Annals of Human Biology, 21: 407-415. DOI: 10.1080/03014469400003422

Bodzsár, É.B. (1980): Physique and sexual maturation. Anthropologiai Közlemények, 24: 23-30.

Bodzsár, É.B. (1991): The Bakony growth study. Humanbiologia Budapestinensis, 22.

Bodzsár, É.B. (2001): A pubertás auxológiai jellemzői. Humanbiologia Budapestinensis, Suppl. 28.

Bodzsár, É.B. (2003): A pubertáskor. ELTE Eötvös Kiadó, Budapest. pp. 66-75.

Bodzsár, É.B., Pápai, J. (1989): Maturation and body composition. Humanbiologia Budapestinensis, 19: 215-218.

Bodzsár, É., Zsákai, A. (2004): Humánbiológia. Gyakorlati kézikönyv. Eötvös Kiadó, Budapest. p. 300.

Bodzsár, É., Zsákai, A. (2012): Magyar gyermekek és serdülők testfejlettségi állapota, Országos Növekedésvizsgálat 2003-2006 - Body developmental status of Hungarian children and adolescents, Hungarian National Growth Study 2003-2006. Plantin Press, Budapest. p. 240.

Bodzsár, É., Zsákai, A., Tausz, K. (2013): Hátrányos helyzetü kistérségek gyermekei nemi érésének mintázata. Anthropologiai Közlemények, 54: 3-11.

Bolonchuk, W.W., Siders, W.A., Lykken, G.I., Lukaski, H.C. (2000): nutritional assessment. American Journal of Human Biology, 12: 167-180. DOI: 10.1002/(SICI)15206300(200003/04)12:2<167::AID-AJHB2>3.0.CO;2-3

Carter, J.E.L. (1975): The Heath-Carter somatotype method. San Diego University Press, San Diego. p. 145.

Carter, J.E.L., Heath, H.B. (1990): Somatotyping - development and applications. Cambridge University Press, Cambridge - New York - Port Chester - Melbourne - Sydney. p. 525.

Chaouachi, M., Chaouachi, A., Chamari, K., Chtara, M., Feki, Y., Amri, M., Trudeau, F. (2005): Effects of dominant somatotype on aerobic capacity trainability. British Journal of Sports and Medicine, 39: 954-959. DOI: 10.1136/bjsm.2005.019943

Claessens, A.L., Lefevre, J., Philippaerts, R., Thomis, M., Beunen, G. (2004): Relation between body composition and Heath-Carter somatotype in adult males. In Bodzsár, É.B., Susanne, C. (Eds) Physique and body composition. Biennial Books of EAA, 3. Eötvös University Press, Budapest. pp. 41-51.

Claessens, A.L., Malina, R.M., Lefevre, J., Beunen, G., Stijnen, V., Maes, H., Veer, F.M. (1992): Growth and menarcheal status of elite female gymnasts. Medicine and Science in Sports and Exercise, 24: 755-763.

Considine, R.V., Sinha, M.K., Heiman, M.L., Kriauciunas, A., Stephens, T.W., Nyce, M.R., Ohannesian, J.P., Marco, C.C., McKee, L.J., Bauer, T.L., Caro, J.F. (1996): Serum immunoreactive-leptin concentrations in normal-weight and obese humans. New England Journal of Medicine, 334: 292-295. DOI: 10.1056/NEJM199602013340503

Dar, R.R., Lone, F.A.,Sheikh, A.A., Ahmad, S.F., Islam, S.T., Lakhani, N. (2017): Role of leptin in reproduction. Theriogenology Insight, 7(2): 113-121.

Davison, K.K., Susman, E.J., Birch, L.L. (2003): Percent body fat at age 5 predicts earlier pubertal development among girls at age 9. Pediatrics, 111(4): 815-821.

Demerath, E.V., Li, J., Sun, S.S., Chumlea, W.C., Remsberg, K.E., Czerwinski, S.A., Towne, B., Siervogel, R.M. (2004): Fifty-year trends in serial body mass index during adolescence in girls: the Fels Longitudinal Study. American Journal of Clinical Nutrition, 80: 441-446.

Drywien, M., Frackiewicz, J., Gornicka, M., Wielgosz, J., Sobolewska, A., Kulik, S. (2016): Influence of the somatotype on intake of energy and nutrients in women. Anthropological Notebooks 22 (3): 147-157. 
Ebling, F.J.P. (2005): The neuroendocrine timing of puberty. Reproduction, 129: 675-683. DOI: 10.1530/rep.1.00367

Erdélyi, G.J. (1962): Gynaecological survey of female athletes. Journal of Sports Medicine and Physical Fitness, 2: 174-179.

Farmosi, I. (1982): Adatok a sportoló nők menarchekorához. Sportorvosi Szemle, 23: 11-17.

Foster, D.L., Nagatani, S. (1999): Physiological perspectives on leptin as a regulator of reproduction: Role in timing puberty. Biology of Reprocuction, 60: 205-215. DOI: 10.1095/biolreprod60.2.205

Frisch, R.E. (1972): Critical weight at menarche, initiation of the adolescent growth spurt and control of puberty. In: Grumbach, M.M., Grave, G.D., Mayer, F.E. (Eds) Control of puberty. John Wiley \& Sons, New York - London - Sydney - Toronto. pp. 403-423.

Frisch, R.E. (1980):. Pubertal adipose tissue: is it necessary for normal sexual maturation? Evidence from the rat and human female. Federation Proceedings, 39: 2395-2400.

Frisch, R.E., McArthur, J.W. (1974): Menstrual cycles: fatness as a determinant of minimum weight for height necessary for their maintenance or onset. Science, 185: 949-951.

Garn, S.M., LaVelle, M., Rosenberg, K., Hawthorne, V. (1986): Maturational timing as a factor in female fatness and obesity. American Journal of Clinical Nutrition, 43: 879-883.

Hunt, E.E., Cocke, G., Gallagher, J.R. (1958): Somatotype and sexual maturation in boys: a method of developmental analysis. Human Biology, 30: 73-91.

Kaplowitz, P.B. (2008): Link between body fat and the timing of puberty. Pediatrics, 121 (Suppl. 3): S208-S217. DOI: 10.1542/peds.2007-1813F

Kaplowitz, P.B., Slora, E.J., Wasserman, R.C., Pedlow, SE, Herman-Giddens, M.E (2001): Earlier onset of puberty in girls: relation to increased body mass index and race. Pediatrics, 108: 347-353. DOI: $10.1542 /$ peds.108.2.347

Kennedy, G.C., Mitra, J. (1963): Body weight and food intake as initiating factors for puberty in the rat. Journal of Physiology, 166: 408-418.

Lassek, W.D., Gaulin, S.J.C. (2007): Brief Communication: Menarche is related to fat distribution. American Journal of Physical Anthropology, 133: 1147-1151. DOI: 10.1002/ajpa.20644

László, A. (1998): Sportolók érése és testi fejlődése. Szakdolgozat. ELTE, TFK, Budapest.

Malina, R.M. (1983): Menarche in athletes: a synthesis and hypothesis. Annals of Human Biology, 10: $1-24$.

Malina, R.M. (1986): Maturational considerations in elite young athletes. In: Day, J.A.P. (Ed.) Perspectives in Kinanthropometry. Human Kinetics, Champaign. pp. 29-43.

Malina, R.M., Bouchard, C. (1991): Growth, Maturation and Physical Activity. Human Kinetics, Champaign. pp. 229-463.

Malina, R.M., Rarick, G.L. (1973): Growth, physique and motor performance. In: Rarick, G.L. (Ed.) Physical activity. Academic Press, New York - San Francisco - London. pp. 125-154.

Malina, R.M., Spirduso, W.W., Tate, C., Baylor, A.M. (1978): Age at menarche and selected menstrual characteristics in athletes at different competitive levels and in different sports. Medicine and Science in Sports, 10(3): 218-222.

Marta, C.C., Marinho, D.A., Barbosa, T.M., Carneiro, A.L., Izquierdo, M., Marques, M.C. (2013): Effects of body fat and dominant somatotype on explosive strength and aerobic capacity trainability in prepubescent children. Journal of Strength and Conditioning Research, 27(12): 3233-3244. DOI: $10.1519 /$ JSC.0000000000000252

Martin, R., Saller, K. (1957/1966): Lehrbuch der Anthropologie. 3. Band. Fischer, Stuttgart.

Matkovic, V., Ilich, J.Z., Skugor, M., Badenhop, N.E., Goel, P., Clairmont, A., Klisovic, D., Nahhas, R.W., Landoll, J.D. (1997): Leptin is inversely related to age at menarche in human females. Journal of Clinical Endocrinology and Metabolism, 82: 3239-3245. DOI: $\underline{10.1210 / j c e m .82 .10 .4280}$

Meier, U., Gressner, A.M. (2004): Endocrine regulation of energy metabolism: Review of pathobiochemical and clinical chemical aspects of leptin, ghrelin, adiponectin, and resistin. Clinical Chemistry, 50(9): 1511-1525. DOI: 10.1373/clinchem.2004.032482 
Pápai, J. (1985): Korán és későn érett leányok testfejlettsége és testalkata. Anthropologiai Közlemények, 29: 89-96.

Pápai, J. (1996): Biológiai életkorok és testi fejlődés. In: Tonkáné, M., Szabó, T. (Szerk.) Utánpótlás-nevelési Konferencia. OTSH, Budapest. pp. 56-65.

Pápai, J. (2001): Sportoló leányok testalkati változásai az érés során. Magyar Sporttudományi Szemle, 3-4: 37-40.

Pápai, J. (2002): Physiological age and changes in body dimensions. In: Eiben, O.G., Bodzsár, É.B., Zsákai, A. (Eds) Children and Youth at the Beginning of the 21st Century. Humanbiologia Budapestinensis, 27: 67-75.

Pápai, J., Szabó, T. (1986): The physique of urban girls. Anthropologiai Közlemények, 30: $221-225$.

Pápai, J., Tróznai, Zs., Négele, Z. (2013): Sexual maturation type and body structure of girls. Anthropologiai Közlemények, 54: 13-23.

Pápai, J., Tróznai, Zs., Szabó, T., Szabó, A. (2012): Fat pattern of athlete and non-athlete girls during puberty. Anthropological Review, 75: 41-50.

Peeters, M.V., Thomis, M.A., Loos, R.J.F., Derom, C.A., Fagard. R., Claessens, A.L., Vlietinck, R.F., Beunen, G.P. (2007): Heritability of somatotype components: a multivariate analysis. International Journal of Obesity, 31: 1295-1301. DOI: 10.1038/sj.ijo.0803575

Rahmawati, N.T., Hastuti, J., Suriyanto, R.A. (2017): Relationship between somatotype and age at menarche among adolescent girls in Yogyakarta Province, Indonesia. Pakistan Journal of Nutrition, 16(5): 351-358. DOI: $10.3923 /$ pjn.2017.351.358

Ross, W.D., Carter, J.E.L., Roth, K., Willimczik, K. (1977): Sexual dimorphism in sport by a (a) somatotype I-index. In: Eiben, O.G. (Ed.) Growth and Development: Physique. Symposia Biologica Hungarica, 20. Akadémiai Kiadó, Budapest. pp. 363-376.

Sheldon, W., Stevens, S.S., Tucker, W.A. (1940): The varieties of human physique. Hafner Publishing Company, Darien, Connecticut, USA.

Skibinska, A., Sklad, M. (1984): Genetic determination of Heath and Carter somatotype. Biology of Sport, 1: 37-53.

Susanne, C., Bodzsár, É.B. (2004): On physique and body composition. In: Bodzsár, É.B., Susanne, C. (Eds) Physique and body composition. Biennial Books of EAA, 3. Eötvös University Press, Budapest. pp. 9-40.

Szmodis, I. (1977): Physique and growth estimated by Conrad's and Heath-Carter's somatocharts in athletic children. In: Eiben, O.G. (Ed.) Growth and Development: Physique. Symposia Biologica Hungarica, 20. Akadémiai Kiadó, Budapest. pp. 407-415.

Tanner, J.M. (1962): Growth at Adolescence. Blackwell, Oxford, UK. 2nd Edition.

Tanner, J.M., Hiernaux, J., Jarman, S. (1969): Growth and physique studies. In: Weiner, J.S., Lourie, J.A. (Eds) Human Biology. A guide to field methods. International Biological Programme Handbook 9. Blackwell, Oxford - Edinburgh. pp. 1-76.

Tanner, J.M., Whitehouse, R.H., Marubini, E., Resele, L.F. (1976): The adolescent growth spurt of boys and girls of the Harpenden Growth Study. Annals of Human Biology, 3: 109-126.

Trayhurn, P., Beattie, J.H. (2001): Physiological role of adipose tissue: white adipose tissue as an endocrine and secretory organ. Proceedings of the Nutrition Society, 60: 329-339. DOI: 10.1079/PNS200194

Veldre, G. (2004): Heath-Carter somatotype categories and their sexual maturation differences in 12-15-year-old Estonian boys and girls. Papers on Anthropology, 13: 269-285.

Wang, Y.M.D. (2002): Is obesity associated with early sexual maturation? A comparison of the association in American boys versus girls. Pediatrics, 110: 903-910. DOI 10.1542/peds.110.5.903

Weber, E. (1969): Grundriss der biologischen Statistik. 5. Aufl. Fischer, Jena. pp. 81-82.

Wells, J.C.K. (2012): The evolution of human adiposity and obesity: where did it all go wrong? Disease Models and Mechanism, 5: 595-607. DOI: 10.1242/dmm.009613 
Wronska, A., Kmiec, Z. (2012): Structural and biochemical characteristics of various white adipose tissue depots. Acta Physiologica, 205(2): 194-208. DOI: 10.1111/j.1748-1716.2012.02409.x

Zuk, G.H. (1958): The plasticity of the physique from early adolescence through adulthood. Journal of Genetic Psychology, 92: 205-214.

Levelezési cím: Mailing address:
Pápai Júlia

Testnevelési Egyetem, Sporttudományi és Diagnosztikai Laboratórium Istvánmezei út 1-3.

H-1146 Budapest

Hungary

papaijulia7@gmail.com 
